\title{
Development of Discovery Learning Based Physics Learning Module in Energy Discussion
}

\author{
Suci Awaliyah Rizky, Neng Nenden Mulyaningsih, Yoga Budi Bhakti \\ Universitas Indraprasta PGRI Jakarta \\ Email address: nengnendenmulyaningsih@gmail.com
}

\begin{abstract}
Learning physics on the subject of energy still seems difficult for students. To overcome this problem, teaching materials that can clearly explain physics concepts such as modules were needed. The purpose of this research was to develop a physics learning module that is suitable as teaching material referring to the expert validator's assessment. The research method used was the research and development method with the development process using the ADDIE model (Analyze, Design, Development, Implementation and Evaluation). The data collection instrument consisted of material expert validation sheets, media experts and linguists. The results of the study obtained the percentage of the validation value of $83.86 \%$ with a good category. Based on the research results, it can be concluded that the physics learning module based on discovery learning on the subject of energy was valid to be used as an alternative teaching material in physics learning.
\end{abstract}

Keywords: learning physics, module, discovery learning, research and development

Learning is a process of student interaction with teachers and learning resources in a learning environment (Curtis et al., 2020; Boonk et al., 2021). Learning in schools should not only focus on delivering material, but also need to pay attention to students' understanding of the material. The learning process in learning is not only knowing and memorizing the facts but also must understand and master these facts so that it becomes a complete knowledge (Octaviani et al., 2017; Subagiyadi et al., 2020).

Meaningful learning must be carried out in all subject areas, including physics (Zajacova, 2013; Fidan \& Tuncel, 2019). Physics is basically an interesting and fun subject (Liu et al., 2017). This is because there are many physics concepts related to everyday life. However, the reality on the ground is the opposite of this opinion. Many students think that physics is a difficult subject. In the physics learning process, the ability to analyze problems, collect data, determine causation, and make conclusions is required. In fact, students are not accustomed to being immediately active in classroom learning, because they are already familiar with the active teacher's method of starting learning first.

This is in line with the results of research expressed by Duffield et a., (2015) and Karsli et al., (2014), that it is still very difficult to develop a learning model that makes students active in the classroom, because the curriculum with a very broad material coverage and various learning components is very much, so it will hinder learning, and teachers will be more focused on the target material completion compared to teaching with various methods to improve student learning outcomes. In addition, the learning media used were only the 2013 national curriculum standard handbook (Gunawan, 2017).

Based on these conditions, the researcher made an alternative learning media in the form of a learning module based on discovey learning. Discovery learning-based learning in principle does not provide direct knowledge to students, but students must discover new knowledge themselves (Fatihah et al., 2020). Students must find their own knowledge, so that students are required to be active in classroom learning. Discovery learning is learning to find concepts, meanings, and causal relationships through organizing learning carried out by students (Costello, 2017). Discovery learning in the classroom can be done by forming small groups and students discussing a case or problem presented by the teacher. Discovery learning based learning model is very suitable to be combined with learning media in the form of learning modules. Discovey learning based learning module is expected to encourage students to be more active in seeking knowledge, inviting students to think intuition and formulate their own hypotheses. Train students to learn independently, so that they can present physics learning that is more efficient and effective for students to use in learning physics. Therefore, the main objective of this research is to develop a physics learning 
module based on discovey learning on energy material, so that this module can be used as teaching material.

\section{METHOD}

This research was a research development or Research and Development (R \& D). The research model used in this study was ADDIE. The ADDIE development model consists of 5 stages, namely: (1) Analyze (2) Design (3) Development (4) Implementation (5) Evaluation. However, this research was only carried out until the fourth stage that is implementation.

The validity test of discovery learningbased physics learning modules on the subject of energy was carried out by expert validators in the material field, media experts and linguists. The number of validators was 9 people. Furthermore, each validator was asked to provide a general assessment of the feasibility or validity of the module being developed.

The data analysis technique used in this research was descriptive analysis, namely by calculating the percentage of the validation value as follows:

$$
\%=\frac{\text { score obtained }}{\text { maximum score }} \times 100 \%
$$

The development stage of a physics learning module based on discovery learning on the subject of energy using the ADDIE model can be seen in Figure 1.

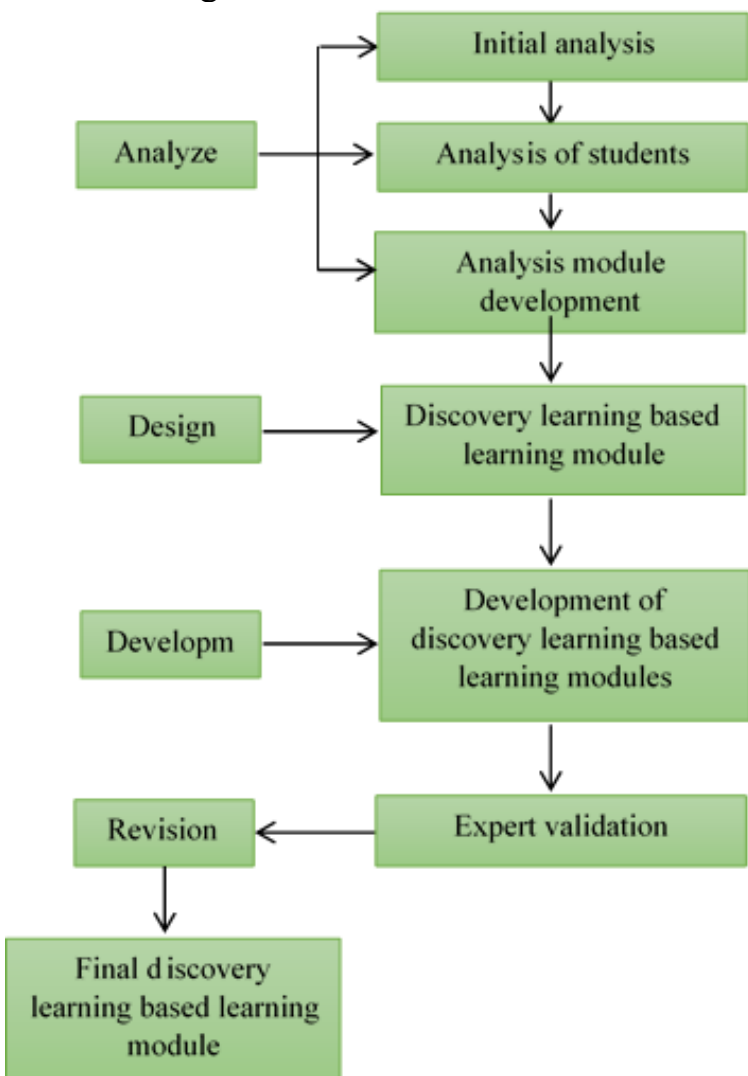

Figure 1. Module Development Stage
The feasibility level of products from research and development products was identified with the percentage score. The greater the percentage score of the results of the data analysis, the better the feasibility level of the product development research results. The criteria for making decisions in validating learning media can be seen in Table 1 (Saraswati et al., 2020).

Table 1. Eligibility Criteria for Instructional Media

\begin{tabular}{lll}
\hline No. & Percentage (\%) & Remarks \\
\hline 1 & $80 \%-100 \%$ & Very good \\
2 & $60 \%-79.99 \%$ & Good \\
3 & $50 \%-59.99 \%$ & Fair \\
4 & $0-49,99 \%$ & Poor \\
\hline
\end{tabular}

\section{RESULTS AND DISCUSSION}

\section{Results}

The product produced in this development research was a physics learning module based on discovery learning on the subject of energy. This module product was developed by researchers with the aim of being an alternative teaching material for teachers and as a medium for independent learning for students. The average validation results of material experts can be seen in Table 2 - Table 4.

Table 2. The Average Validation Results of Material Experts

\begin{tabular}{llll}
\hline No. & Criteria & $\%$ & Remarks \\
\hline 1 & Grammar & 86.11 & Very good \\
2 & $\begin{array}{l}\text { Content of the } \\
\text { material }\end{array}$ & 94.44 & Very good \\
3 & Illustration & 91.67 & Very good \\
\hline Average & 90.74 & Very good \\
\hline
\end{tabular}

Table 3. The Average Validation Results of Media Experts

\begin{tabular}{llll}
\hline No. & Criteria & $\%$ & Remarks \\
\hline 1 & Graphic design & 80.00 & Very good \\
2 & View & 77.78 & Good \\
3 & Practicality & 88.89 & Very good \\
\hline Average & 82.23 & Very good \\
\hline
\end{tabular}

Table 4. The Average Validation Results of Linguists

\begin{tabular}{llll}
\hline No. & Criteria & $\%$ & Remarks \\
\hline 1 & Straightforward & 80.56 & Very good \\
2 & Communicative & 75.00 & Good \\
3 & $\begin{array}{l}\text { Suitability with } \\
\text { the }\end{array}$ & 83.33 & Very good \\
& $\begin{array}{l}\text { development of } \\
\text { students }\end{array}$ & \\
& $\begin{array}{l}\text { Compliance } \\
\text { with language }\end{array}$ & 70.83 & Good \\
& rules & & \\
\hline Average & 77.43 & Good \\
\hline
\end{tabular}

\section{DISCUSSION}

This study aims to produce a feasible discovery learning-based physics module as an alternative to teaching materials in physics 
learning. The development of this product consists of 3 stages, namely the stages of define, design, and development. The feasibility and validity of discovery learning-based physics modules can be seen based on the percentage value of the feasibility of the module.

In the analysis phase which consists of initial analysis, student analysis analysis and module development analysis. From this analysis, it is known about the characteristics of students, teaching materials and physics learning materials needed in developing module products as an alternative to teaching materials in class. This is in line as expressed by Zaimil et al., (2016) and Jamilah et al., (2017) that currently learning modules have become an option in supporting learning activities, especially in the era of distance learning that was imposed during the COVID-19 pandemic. Students were required to be more independent in learning, even though the teacher continues to provide assistance.

This initial analysis relates to problems in learning physics, school conditions, and the completeness of learning media. The initial analysis aims to determine the basic problems faced in learning physics in schools including curriculum analysis and field problems so that the development of learning tools is needed. The solution adopted by the researcher is to develop discovery learning-based teaching materials in the form of learning modules.

Analysis of the characteristics of students was carried out by examining relevant theories, interviews with physics teachers at senior high school (SMAN 6 Tangerang Selatan), and observations during learning activities in class. This analysis was carried out to find out in detail the psychological and physical condition of students who will use the tested module. The results of this analysis were used as a guide for compiling and developing the module. The characteristics of students who will be analyzed were the characters of the students of SMAN 6 Tangerang Selatan. This is considered important to do because it is to determine the level of ability of students, student motivation, and other aspects.

Analysis of the development of this module was carried out by reviewing references that discuss aspects that need to be considered in module development so that they can be classified into proper and good modules. In this analysis, an assessment was carried out on the aspects of making and developing a good module, namely modules that meet the feasibility aspects of content, aspects of presentation feasibility, aspects of graphic feasibility and aspects of language feasibility.
This analysis also refers to the results of curriculum analysis and analysis of the characteristics of students, because this analysis was also the main aspects of module development. In addition to the module aspects, an analysis was also carried out on the discovery learning model which is the basis for the developed module, in order to obtain a discovery-based physics module on the subject of energy in class X SMAN 6 Tangerang Selatan.

At the design stage the learning module consists of the stage of selecting instructional media, selecting the format of instructional media and the initial design of the product. At this stage it demands creativity from the developer. The selection of instructional media designed to support discovery learning-based physics modules includes preparing problem themes related to the module learning concept according to the learning concept to be achieved, as well as related instruments that must be in a based learning module. Instruments in the form of student worksheets or practicum instructions.

The initial design of the first learning device resulted in a learning instrument design, namely a draft learning implementation plan and a Discovery Learning-based Physics Module media. The format used in planning the lesson plan refers to the 2013 curriculum format (K13) which was exemplified in learning physics by adopting the format given by the physics subject teacher at SMAN 6, South Tangerang city. The researcher compiled an initial draft of the research instrument in the form of a physics module based on discovery learning, and an expert validation sheet.

Qualitative data obtained from the validation results of material experts, media experts and linguists. The results of the validation are in the form of suggestions or improvements for the discovery learning-based physics learning module. Material expert validation is in the form of a questionnaire filled out by material experts to determine the feasibility of the module from the material aspects of the discovery learning-based physics learning module. The material expert validator consists of 3 experts, namely Mr. Alpi Mahisha Nugraha, M.Si. (Lecturer at Indraprasta University PGRI's Physics Education Study Program), Mrs. Ria Asep Sumarni, M.Pd.Si. (Lecturer at Indraprasta University PGRI's Physics Education Study Program) and Ms. Nurhayati, S.T. (Physics teacher at SMAN 6 Tangerang Regency). Suggestions for improvement from material experts include including the friction force formula, equating the writing of physics quantity symbols using italics (italic), the questions presented must meet the 
categories of lower order thinking skills (LOTS), middle order thinking skills (MOTS), and higher order thinking skills (HOTS).

Media expert validation was in the form of a questionnaire filled out by media experts to determine the feasibility of the module from the media aspect in the discovery learning-based physics learning module. The media expert validator consists of 3 experts, namely $\mathrm{Mr}$. Dasmo, M.Pd. (Head of the Physics Education Study Program, Indraprasta University PGRI), Mrs. Irnin Agustina D.A, M.Pd. (Lecturer in the Physics Education Study Program, Indraprasta University PGRI) and Mrs. Indica Yona Okyranadia, M.Pd. (Lecturer at the Physics Education Study Program, Indraprasta University PGRI).

The test results on the graphic aspect get an average percentage of feasibility of $80.00 \%$ in the good / valid category. In the aspect of presenting the media, the average percentage of feasibility is $77.78 \%$ with the category good enough / quite valid. In the aspect of using the media, the average percentage of feasibility is $88.89 \%$ with the good / valid category. Overall, based on the results of the three validators, the feasibility of the material in the discovery learning module as a whole is $81.25 \%$ with the good / valid category, meaning that the module developed is suitable to be used as an alternative teaching material with notes or suggestions for improvement. The following notes or suggestions for improvements from expert validators and improvements that have been made. In physics learning module based on discovery learning, namely improving the cover to make it more attractive as shown in Figures 2 and 3, adding the validator's name on the French page, presenting a more flexible concept map, improving fonts and writing, improving formula equation, and improve the completeness of the module components.

The test results on the feasibility aspect get an average percentage of worthiness of $80.56 \%$ in the good / valid category. In the communicative aspect, the average percentage of eligibility is $75 \%$ with the category good enough / valid enough. In the aspect of suitability, students get an average percentage of eligibility of $83.33 \%$ in the good / valid category. In the aspect of suitability of language rules, the average percentage of feasibility is $70.83 \%$. Overall, based on the results of the three language eligibility validators in the discovery learning module, overall it is $78.13 \%$ with the category good enough / valid enough, meaning that the module developed is quite feasible to be used as an alternative teaching material with notes or suggestions for improvement. The following are notes or suggestions for improvements from expert validators and improvements that have been made. In physics learning module based on discovery learning, namely sorting answers from smallest to largest, improving bibliography, correcting words according to good and correct Indonesian rules.

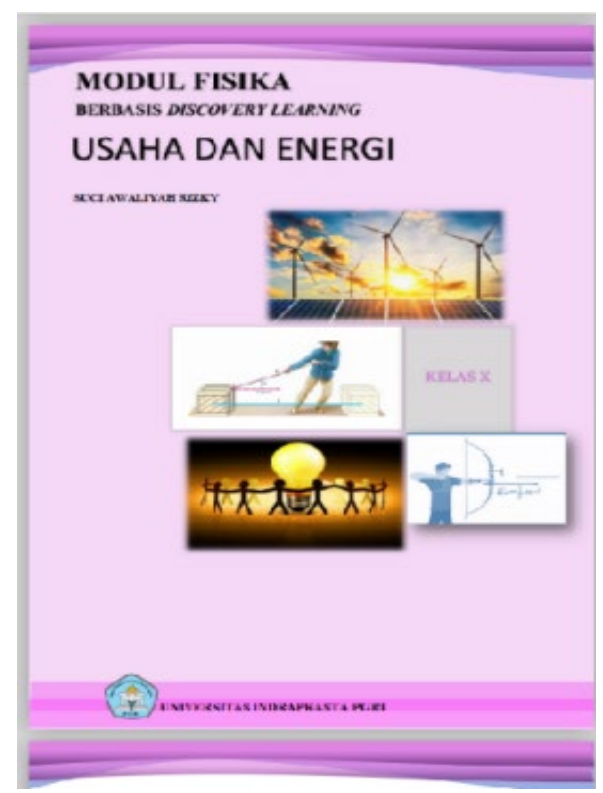

Figure 2. Cover Modules Before Revision

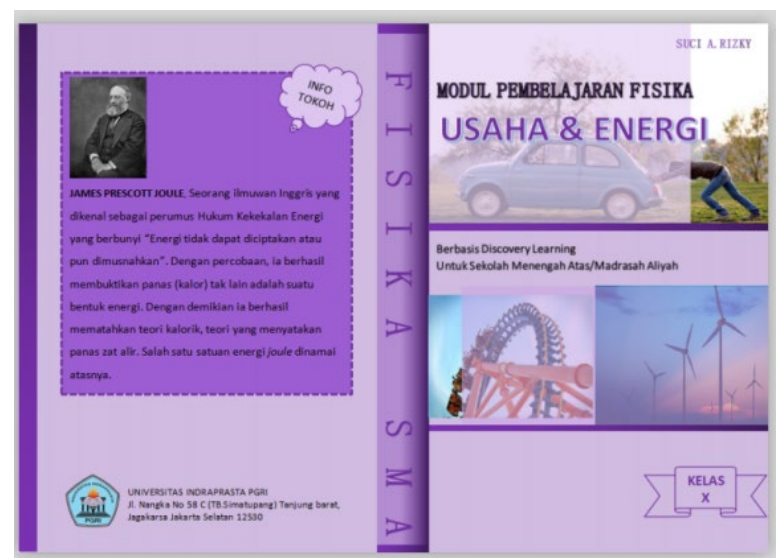

Figure 3. Cover Modules After Revision

The linguist validation is in the form of a questionnaire filled out by linguists to determine the feasibility of the module from the linguistic aspects of the discovery learning-based physics learning module. The media expert validator consists of 3 experts, namely Mrs. Eka Septiani, S.S., M.Pd. (Lecturer at the Indonesian Language Study Program, Indraprasta University PGRI), Ms. Nur Indah Sari, M.Pd. (Lecturer at the Indonesian Language Study Program, Indraprasta University PGRI), and Mrs. Ria Anggari Putri, M.Pd (Jakarta State University linguist).

The test results on the linguistic aspect obtained an average percentage of feasibility of 
$86.11 \%$ with the good / valid category. In the aspect of material suitability, the average percentage of feasibility is $94.44 \%$ in the good / valid category. In the illustration aspect, the average percentage of feasibility is $91.67 \%$ with the good / valid category. Overall, based on the results of the three validators, the feasibility of the material in the discovery learning module as a whole is $92.22 \%$ with the good / valid category, meaning that the module developed is feasible to be used as an alternative teaching material with notes or suggestions for improvement. The following notes or suggestions for improvement from the linguist validator, namely including a point at the end of the title, correcting words according to good and correct Indonesian rules, correcting paragraphs that have not been aligned right-left, adding dots to each question, ordering the answers to questions from smallest to the biggest, improvements to the bibliography, improvements to the author's bio and pay attention to the use of general guidelines for Indonesian spelling (PUEBI) in sentences.

Discovery learning-based physics learning module has been successfully developed. The module that has been developed has also been validated by 9 validators, consisting of 3 groups each of 3 material experts, 3 media experts and 3 language experts. Material experts and media experts stated that the modules that had been developed were very good, with an average rating of $90.74 \%$ and $82.23 \%$, respectively. Meanwhile, the language expert stated that the module that has been developed has used grammar in accordance with the rules of Indonesian which is good and correct, with an average assessment score of $77.43 \%$ and is included in the good category.

The results of the development of modules that have been compiled based on the guidebook for compiling the modules, and the material in the modules are arranged based on the syntax of discovery learning with the study of energy subjects This module specification is printed in full color, in which there are examples of questions and their discussion. In addition, there are also enrichment materials to broaden students' insights, such as physics figures and interesting phenomena on Earth related to the concept of energy. The module that has been developed is also equipped with an appendix covering the values for quantities and units, prefixes, and conversions.

The module that has been developed is also equipped with a practical guide to the concept of energy in the form of the law of conservation of energy and the transfer of energy in solid, liquid and gas mediums. At the end of each sub-chapter there are wisdom words or words of wisdom from scientists, so that students are more motivated in learning.

Students can evaluate their own learning outcomes by answering evaluation questions and checking the results by looking at the answer keys that are available in the module after completing the evaluation questions. How to calculate the learning outcomes obtained by students has been described in detail in the feedback and follow-up. In addition, the image on the module cover is in accordance with the physics subject matter of energy. The advantage of this module is that it can be used anytime and anywhere because it does not require additional tools to use it, and it can increase students' knowledge because the content of the module is equipped with various additional information, such as physics figures, quantities and units, interesting phenomena on Earth, as well as other additional information. In addition, the module is also made with discovery learning syntax so that it can increase student motivation in learning. The weakness of this module is the limited learning model that can be applied by teachers and students in teaching and learning activities on the subject matter of physics on energy.

\section{CONCLUSION}

Based on the results of the study, it can be concluded that the learning modules that have been developed based on material aspects, media aspects and language aspects were suitable for use in learning activities in schools on the subject of energy.

\section{REFERENCES}

Boonk, L.M., Ritzen, H., Gijselaers, H.J.M. \& BrandGruwel, S. (2021). Stimulating parental involvement in vocational education and training (VET): A case study based on learning histories of teachers, principals, students, and their parents. Teaching and Teacher Education, 100, 103279. https://doi.org/10.1016/j.tate.2021.103279.

Costello, M. (2017). The Benefits of Active Learning: Applying Brunner's Discovery Theory to the Classroom: Teaching Clinical DecisionMaking to Senior Nursing Students. Teaching and Learning in Nursing, 12(3), 212-213, https://doi.org/10.1016/j.teln.2017.02.005.

Curtis, E., Brownlee, J.L. \& Spooner-Lane, R. (2020). Teaching perspectives of philosophical inquiry: Changes to secondary teachers' understanding of student learning and pedagogical practices. Thinking Skills and Creativity, 38, 100711. https://doi.org/10.1016/j.tsc.2020.100711. 
Duffield, S. \& Whitty, S.J. (2015). Developing a systemic lessons learned knowledge model for organisational learning through projects. International Journal of Project Management, 33(2),

311-324. https://doi.org/10.1016/j.ijproman.2014.07.00 4.

Fatihah, S.H., Mulyaningsih, N.N \& Astuti, I.A.D. (2020). Inovasi Bahan Ajar Dinamika Gerak dengan Modul Pembelajaran Berbasis Discovery Learning. Jurnal Pendidikan Fisika dan Teknologi, 6(2), 175-182.

Fidan, M. \& Tuncel, M. (2019). Integrating augmented reality into problem based learning: The effects on learning achievement and attitude in physics education. Computers \& Education, 142 , 103635 . https://doi.org/10.1016/j.compedu.2019.1036 35 .

Gunawan, I. (2017). Indonesian Curriculum 2013: Instructional Management, Obstacles Faced by Teachers in Implementation and the Way Forward. Advances in Social Science, Education and Humanities Research, 128, 5663.

Jamilah, Jampel, I.N. \& Parmiti, D.P. (2017). Pengembangan modul pembelajaran berbasis discovery mata pelajaran IPA siswa SD no 1 Baktiseraga kelas IV. Jurnal EDUTECH Universitas Pendidikan Ganesha, 5(2), 189198.

Karsli, F. \& Ayas, A. (2014). Developing a Laboratory Activity by Using 5e Learning Model on Student Learning of Factors Affecting the Reaction Rate and Improving Scientific
Process Skills. Procedia - Social and Behavioral Sciences, 143, 663-668. https://doi.org/10.1016/j.sbspro.2014.07.460.

Liu, C.Y., Wu, C.J., Wong, W.K., Lien, Y.W. \& Chao, T.K. (2017). Scientific modeling with mobile devices in high school physics labs. Computers \& Education, 105, 44-56. https://doi.org/10.1016/j.compedu.2016.11.00 $\underline{4}$.

Octaviani, W., Gunawan, G. \& Sutrio., S. (2017). Pengembangan Bahan Ajar Fisika Kontekstual Untuk Meningkatkan Penguasaan Konsep Fisika. Jurnal Pendidikan Fisika dan Teknologi, 3(1), 1-7.

Saraswati, D.L., Mulyaningsih, N.N., Asih, D.A.S. \& Ardy, V. (2020). Development of Learning Media-Based Digital Book on Modern Physics Learning. 1st International Conference on Folklore, Language, Education and Exhibition (ICOFLEX 2019), 338-343.

Subagiyadi, P., Bhakti, Y.B. \& Mulyaningsih, N.N. (2020). Pengaruh Metode Pembelajaran Inquiry Pictorial Riddle Terhadap Hasil Belajar Fisika Pada Sekolah Menengah Atas Negeri 85 Jakarta. Navigation Physics: Journal of Physics Education, 2(1), 41-46.

Zajacova, B. (2013). Learning Styles in Physics Education: Introduction of Our Research Tools and Design. Procedia - Social and Behavioral Sciences, 106, 1786-1795. https://doi.org/10.1016/j.sbspro.2013.12.201.

Zaimil, R. \& Rosmiyati. (2016). Tahap design pengembangan modul berbasis masalah pada perkuliahan geometri analitik bidan di FKIP Ummy Solok. Lemma, 3(1), 59-77. 